\title{
INTRODUCTION
}

Ursula Phillips

Zofia Nałkowska (1884-1954) was one of the most outstanding Polish writers and cultural figures of the first half of the twentieth century, recipient of many prestigious literary awards both before and after 1945. She is regarded as a pioneer of the psychological novel in Polish, following Karol Irzykowski (1873-1944) and Stefan Żeromski (1864-1925). Having drawn inspiration in her early years from Nietszche, Schopenhauer, and Bergson, her mature prose was more deeply influenced by the psychological realism of Stendhal and Flaubert, Dostoevsky and Proust. Her approach to human behavior, interhuman relations, and personality formation, and to their portrayal in literature may be said to anticipate the work of novelist and playwright Witold Gombrowicz (1904-1969) (Kirchner 1984). In addition, she was a significant voice promoting the visibility of women in early-twentieth-century literature, alongside other prominent Polish authors active between the two world wars, such as Maria Dąbrowska, Pola Gojawiczyńska, Maria Jehanne Wielopolska, Helena Boguszewska, Maria Kuncewiczowa, Wanda Melcer, Irena Krzywicka, and others (Kraskowska 1999; Borkowska 2001b).

Daughter of well-known scholar, geographer, and critic Wacław Nałkowski (1851-1911), she grew up in Warsaw in the politically progressive atmosphere of her father's intellectual milieu, immersed in the literature of the Modernist fin-de-siècle, and personally acquainted with leading Polish cultural figures of the time. An admirer of philosopher and cultural critic Stanisław Brzozowski (1878-1911), she was an advocate throughout her life of liberal ideas, social tolerance, and humanitarian empathy with 
victims of oppression and suffering. She was associated, for example, with the progressive literary group Suburb (Przedmieście, 1933-1937). After World War II she was a member of the official Commission for Investigating Nazi Crimes in Poland, an experience that found powerful literary expression in her collection of short prose Medallions (Medaliony, 1946).

During Nałkowska's lifetime, her native land-from 1795 to 1918 partitioned between three competing empires (Russia, Austria, and Prussia) - underwent a series of fundamental upheavals that formed the background, even if not explicitly stated, to most of her literary activity: the 1905 revolution as it affected the western gubernias of the Russian Empire, of which Warsaw was a part from 1815 until 1918; the First World War, the activity of patriotic legions fighting for Polish national independence on both sides of the conflict, and the establishment of the Second Republic of Poland after the war; the Polish-Soviet War of 1920; the attempts in the early 1920s to establish a parliamentary democracy; Józef Piłsudski's coup d'état in May 1926; the Nazi and Soviet invasions of September 1939; the Second World War; the Holocaust; the Warsaw Ghetto Uprising, 1943, and the Warsaw Uprising, 1944; the establishment of communist power in a postwar Polish state with drastically reconfigured geographic and ethnic boundaries. Also of fundamental importance to her consciousness was the political situation in Europe generally, as well as contemporary artistic and literary developments that were taking place in elite European intellectual and cultural circles, especially French, to whose legacy she aspired and with whom she established personal contacts.

Zofia Nałkowska began to write as a teenager, poetry initially, as well as in diaries, which were to accompany her throughout her writing career, with some interruptions, and which themselves became a significant formative element in her own selfcreation as an author, even arguably literary works in their own right (Kirchner 2011, 789-826). The existence of these diaries, 
gradually published in six volumes under Hanna Kirchner's editorship, was not known when Nałkowska's novels and short stories first appeared. ${ }^{1}$

Her literary production spans early Modernism-known in the Polish context as the Young Poland (Młoda Polska) movementand then the more realistically oriented psychological novel, especially following the outbreak of World War I and the occupation of Warsaw by the Germans. It is then when Nałkowska's focus switched from self to other people, to the "world beyond me," to public life and collective concerns, including the phenomenon and psychology of war itself (irrespective of its causes). Her earlier, pre-1914 period is dominated by her private intellectual and emotional development and self-creation as a woman. Her debut as a novelist came in 1906, when she published her first full-length prose fiction in book form-the three-part novel Women (Kobiety). ${ }^{2}$ The theme of female internal life never left her, but from 1914 onward the focus shifted from narcissistic, Nietzschean individualism, and identity as a New Woman-celebrating empowered female sexuality and challenging traditional women's roles and motherhood in works such as Contemporaries (Rówieśnice, 1909), Narcyza (1910), Snakes and Roses (Węże i róże, 1915), the short story collections Little Kitten or White Tulips (Koteczka czyli biate tulipany, 1909) and Mirrors (Lustra, 1913) - to the trauma of war and occupation as it affected Poles and their striving to re-establish political independence-notably in the collection Blood Secrets (Tajemnice krwi, 1917) and the novel Count Emil (Hrabia Emil, 1920).

Her primary focus became-and would always remain - the sufferings of human society at large, transcending ethnic and cultural boundaries and culminating eventually in her most powerful existential statement, the novel about several generations of a family driven by the urge to self-annihilation entitled The Impatient Ones (Niecierpliwi, 1939). Her writing would become characterized above all by a profound humanitarian empathy with 
all living creatures, including animals (she published three sets of short stories devoted to human interaction with animals ${ }^{3}$ ), acutely aware of suffering-physical, psychological, and moral. The general impression that emerges from her work is of a sense of human consciousness being the highest instance and value, a consciousness whose assessment of human behavior is ultimately tragic (beyond or irrespective of any religious or ideological imperatives). It has even been argued that she was already psychologically prepared for what she witnessed during the Nazi occupation of Warsaw and, following that, in her postwar capacity as a member of the Commission for Investigating Nazi Crimes. This all merely confirmed what she had already concluded about human nature, as her motto to Medallions suggests: "People dealt this fate to people." ${ }^{4}$ Grażyna Borkowska puts it this way:

Her experiences as a woman left her several times on the edge of a precipice. The war, which was objectively terrible, brought nothing new to Nałkowska's inner perception of the world, nor did it change anything in her observation of herself or other people. Accustomed to an environment of existential pessimism, Nałkowska was internally prepared for the war. She knew how to survive war because she knew how to survive life. (2001b, 153)

I would like to suggest, first, that some of the human experiences Nałkowska heard about during her stay in Switzerland in 1925 contributed to this view of human nature and, second, that the sufferings of several of the female characters in her novel may reflect-at least partially_some of her own agonies as a woman. Choucas appeared in the middle of a series of novels written in the 1920s and 1930s, in which Nałkowska, a close witness as a result of her marriage to Jan Gorzechowski to the mechanisms of power and methods of enforcement of the newly independent state, captures the moral and practical dilemmas, ideological conflicts, and administrative chaos of those years 
of political and economic transition. The series includes three other novels-The Romance of Teresa Hennert (Romans Teresy Hennert, 1924), Bad Love (Niedobra miłość, 1928), and Boundaries (Granica, 1935)-and the short story collection Walls of the World (Ściany świata, 1931). Choucas, subtitled An International Novel, is not about Poland itself, but captures rather the tensions between various nations' perceptions of one another in the mid-1920s-prejudices based more on internalized, emotionally driven stereotypes than on any objective criteria, or even on ideological differences (Bolecki 2003). Following the post-First World War political reconfiguration of Europe, Nałkowska's narrator intuits the gravity of the potential consequences of such prejudices against a background of previous atrocity, displacement, or moral bankruptcy experienced by the novel's characters, many of whom were based on real people Nałkowska met in the sanatoria village of Leysin, Switzerland in 1925.

\section{GENESIS OF THE NOVEL CHOUCAS}

Nałkowska was married twice, first (in 1904) to minor poet, publicist, and later pedagogue Leon Rygier (1875-1948), and second (in 1922) to Jan Jur-Gorzechowski (1874-1948), whom Nałkowska had first met in 1916, who was a close associate of Józef Piłsudski, a renowned fighter for Polish independence, and a veteran of Piłsudski's legions. After 1918, in independent Poland, her future husband rose to the position of superintendent of the military police in Wilno (Vilnius). The couple lived first outside Wilno and then in Grodno (present-day Hrodna in Belarus) - where Jur proved to be a tough, politically committed but jealous man, who treated his wife sadistically. As Kirchner observes, "The first ten years of independent Poland would have for Zofia Nałkowska the face of Jan Jur-Gorzechowski" (2011, 181); the marriage lasted until 1929. It was in the company of Gorzechowski that she made the journey in 1925 to Leysin, the 
location that inspired the novel Choucas. The purpose of the visit was the treatment of Gorzechowski, who was suffering with bone tuberculosis in his left hand. Nałkowska herself was not a patient.

After her return to Grodno, Nałkowska, at some point before mid-September 1925, began work on the novel. On 19 September, she records in her diary, almost in passing, amid a passage describing the beauty of the local countryside she explores on horse-back, as well as her constant fears of her own ageing (she would be forty-one on 10 November) and impending deafness, the following: "And then I return, sit down at my desk, write a little of this thing about Switzerland" (1980b, 175). The next mention is on 13 November, when she records its completion: "I have been working a great deal recently, but that doesn't mean I've written a great deal. The rough drafts stacked separately make up a pile six times higher than the final manuscript lying beside them. Its title is Choucas" $(1980 \mathrm{~b}, 184)$. The next diary mention is nine months later on 24 August 1926: "I have written quite a lot, sitting here in Warsaw [...] and still constantly Choucas" (192), suggesting she continued to tinker with it. On 30 August, she records its acceptance by the Warsaw journal The Illustrated Weekly (Tygodnik Ilustrowany), which was a relief to her from the financial perspective, but publication in serial parts was not a form of publication she necessarily welcomed. The passage also betrays some of Nałkowska's characteristic lack of confidence in her artistic abilities and the stressful intellectual and emotional effort involved in creative activity, even a certain tension between the impulse to write and a lack of desire:

Ah, God, what a relief! I have completed Choucas, written for consecutive issues of "The Illustrated Weekly, in haste, in distress, traveling back and forth, in partying and in despair. Such a form of publishing, which cannot be interrupted, is a constant nervous torture, because one is not allowed to be ill, not allowed 
not to make the deadline, not allowed to be unable to write [Z.N.'s emphases]. This is already my fourth, even my fifth book written according to this method. I cannot do it otherwise-mainly because I need the money, and perhaps also from lack of will. Oh, how I dislike writing, how I loathe terribly what I have written! In rare paroxysms of good humor, I unexpectedly discover some value in my books, but it never lasts. I once said, trying to explain my laziness: I would rather read Dostoevsky than write Nałkowska. (1980b, 195-96)

Following acceptance by The Illustrated Weekly, she also sold it to a book publisher: "I am in Warsaw-trying during these past few days to sell my Choucas. At the present time it's a great and difficult task" (1980b, 204; the reference may well be to the period following Piłsudski's coup détat, which had taken place on 12 May). On 1 October she says, "Despite all expectations, I have had two offers for Choucas. I have sold it to Gebethner, though not on the best terms and conditions" (214). Thus the novel appeared first in serial parts in The Illustrated Weekly (1926, numbers 3-36) and then shortly afterward in book form (December 1926), published by Gebethner and Wolff, also in Warsaw, according to her own diary record (19 January 1927). Although the title page of the edition has 1927 , it was common practice for books published in the run-up to Christmas to have the date of the coming year: "In December my Choucas appeared and there have already been a few reviews" (1980b, 229).

The reviews, however, were not numerous, and mostly failed to appreciate the innovative style of the text, or its contents. It was seen by some critics as an apology for pacifism. ${ }^{6}$ While Nałkowska's narrator certainly reveals the sufferings of her protagonists, and juxtaposes these with the unexamined prejudices of other characters, it would be misguided to assign to her an overtly pacifistic agenda, or any ideological role at all beyond the ethical, which itself cannot be reduced anyway here to anything 
more substantial than the expression of an empathic moral consciousness. Nałkowska's narrator primarily bears witness and remains unengaged in the debates between the other characters, while also exemplifying a characteristic feature of Nałkowska's prose: the field of vision and hence of narration is confined to what is visible, or accessible, to the narrator as an actor in medias res. In this novel we have a first-person narrator, neither allknowing nor objective, struggling to understand whatever she observes from her limited perspective.

\section{WHICH BIRDS?}

What species of bird does Nałkowska refer to in her novel's title and text? Clearly, we are dealing with the French name of a particular Alpine bird, which the narrator and her companion enjoy feeding every day on the balcony of their room. From the text, we know that it has a yellow bill and red legs; and Nałkowska's narrator gives detailed information about its various calls, flight patterns, impressive aerodynamics, eating habits, social behavior, and habitat. The birds are obviously found at high altitude. She calls these birds choucas. The French word has the same form in the singular and plural. When she refers to the book in her diary she uses a plural verb, suggesting that she intends (in the title) the birds to be understood as plural, and this is also confirmed by her frequent use of the Polish alternative: Szuki (the Polonized form szuka, singular, also appears frequently in the novel's text). If one looks up the French term choucas in standard French-English dictionaries, the English equivalent is given as "jackdaw" (Polish: kawka). However, the descriptions given in the novel are not of jackdaws. The bird that Nałkowska describes in detail is the Alpine chough (pyrrhocorax graculus); her descriptions correspond to the information given in standard guides relating to this species, not to information given on the jackdaw (corvus monedula). ${ }^{7}$ Nałkowska's narrator 
is aware that the birds are not jackdaws, and she distinguishes between the two species in the novel's text: "Choucas do not caw like jackdaws, but warble or shrill delicately, rather like the chirruping of our own swallows and swifts" (chapter 2).

The Alpine chough is common in the Swiss Alps and regularly distributed above the tree line, while the jackdaw is found at lower altitudes and is even relatively rare in the upper reaches of the Rhône valley, where the novel is set. The French term for the Alpine chough is chocard a bec jaune or chocard des Alpes. The birds described by Nałkowska are chocards not choucas. However, it is a common error among local nonspecialists to confuse the two species, misnaming chocards as choucas; chochards are frequently referred to by the local population as choucas. Hence Nałkowska merely repeats the popular name used by the local people whom she met. ${ }^{8}$

It is significant that Nałkowska's reception of the birds differs fundamentally from that of the locals. Nałkowska's narrator reacts to the birds positively, describing them as gentle and lovable. In chapter 2, for example, we have the following: "they are very peaceable. I never saw them fight among themselves with their yellow bills, even when several descended on the balcony at the same time and couldn't all reach the food"; and in chapter 6: "the birds' glistening forms fall out of the radiant cornflowerblue, cheerful, chirruping, well-adjusted, likeable." The narrator and her companion go to great lengths to prepare food for them, so they can observe and admire them at close quarters. Mentions of the birds by other characters in the novel are more ambiguous. While the narrator is transfixed by the grotesque, painted wooden souvenir choucas in a shop display (all shapes and sizes and colors, but entirely out of proportion with enormous bills and tiny bodies), other (male) characters find them humorous and compare them to Mademoiselle Hovsepian and Mademoiselle Alice (chapter 19). The narrator is taken aback at these comparisons, which have negative connotations, reflecting 
also how the men regard the two women. On a recent visit to the region, seeking myself similar souvenirs, I was unable to find any choucas (or: chocards) among the stacks of toy cows, chamois, marmots, bears and other Alpine fauna. I was assured by several local people that there was a reason for this: namely, the choucas are regarded as birds of ill omen. When they come down to the village for the winter months in search of food-their very presence a sign of bad weather higher up-they even fight other birds, such as magpies. Whilst Nałkowska's narrator describes how a feeding choucas may sometimes become angry and shove another bird off the balustrade (chapter 2), she generally perceives them as peaceable and develops a genuine affection for them. What then are we to make of the novel's closing scene describing a flock of choucas circling over the valley? A nostalgic farewell to the narrator's beloved companions on a par with her leave-taking of her human friends? Or a warning of impending doom hanging over Europe-a finale indeed in tune with the novel's main theme?

\section{THE THEME OF THE NOVEL}

Choucas is a work of fiction; Nałkowska describes it herself as a "novel" and gives it the subtitle An International Novel (powieść internacjonalna). It is not autobiography as such; neither is it reportage, nor a description of Leysin (which is not named in the text). The sanatoria town in the Swiss Alps in 1925 constitutes rather the background, the chief focus being the "foreigners" the narrator meets there. The precise genre status of the work is nevertheless unstable, difficult to define. To some extent it is indeed autobiographical, or at least appears so- "fiction posing as autobiography, or maybe the reverse" (Kirchner 2011, 235)yet the identity and personality of the narrator remains obscure and undeveloped within the novel itself. The narrator, it is clear from the Polish grammatical endings (e.g. past tense of verbs), is a woman, but she is never named; we should therefore beware 
of assuming the narrator is called Zofia Nałkowska. Likewise, during the course of the opening chapter, as the couple feed the birds, it becomes clear that her companion is a man, but it is never made explicit who exactly he is: husband, lover, friend; he too is never named. In the English translation, which makes no gender distinctions for verb endings or adjectives, the gender of the protagonists is initially rendered even more obscure. Even to describe them as "protagonists" is misguided, because the real object of the narrator's attention is not their relationship but the company she meets in the villa-pension, tea rooms, hotels, or other sanatoria. According to Hanna Kirchner, the chief function of the narrator is her "role as witness" - "reporter of the events and phenomena surrounding her": "She collects this knowledge en passant, sharing with the patients of the 'international' pension meals, walks, entertainments. She converses, listens to confessions, contemplates the fates and mentality of the sick people. The plot is a shared, collective one, like the communal table in the pension, but at the same time opens up to new happenings, times, countries, biographies" $(2011,235)$.

The main focus of the novel is thus the interrelationship between the different human beings the narrator meets-as individuals, but also as representatives of their respective European nations, including the various colonies (Madame de Carfort is the wife of a French officer stationed in Morocco; Monsieur Curchaud is a plantation owner in Cambodia, then part of French Indochina). They are not one-dimensional national stereotypes, yet they betray stereotypical nation-specific sentiments and prejudices in relation to one another. As Włodzimierz Bolecki emphasizes in his analysis (2003), these prejudices have no rational or even ideological basis: they consist rather in internalized stereotypes culturally inherited and are driven by emotional factors rather than reasoned concerns, but they are sometimes reinforced by traumatic historical experience that is hard to rationalize and results in dangerous generalizations, for example, 
about all Germans or all Englishmen. The narrator senses danger ahead for civilized interrelations. Meanwhile, she also shows how perfectly friendly individuals, apparently reasonable and civilized, can be full of negative emotional baggage toward individual representatives of other nations, reinforcing stereotypes that encourage hatred, as in the case of affable Monsieur Verdy who hates all Germans because he lost his only son at the Battle of the Marne, or amiable Miss Norah who loathes the Irish, or the Spanish nationalist Carrizales who detests Arabs.

Hatred is underlined as a driving force behind international intercourse. And here we encounter one of the most dramatic subtexts of the novel: the Armenian exiles who witnessed the genocide of 1915-16. Interethnic hatred was a theme not unknown to contemporary Polish literature, 1924 having seen the publication of Stefan Żeromski's novel The Coming Spring (Przedwiośnie), which includes a description of the violent massacre of Armenians in Baku in 1918. ${ }^{9}$ Specific issues relating to the Armenians will be explained in notes to the current translation.

Reflecting on this hatred, the narrator observes that what unites two nations is often their shared hatred of a third; so there will never be peace, because how can all nations unite if they have no one left to hate? "I could not resist the thought that the brotherhood of two nations consists precisely in the fact that they will unite against a third. And hence the brotherhood of all nations, all people, seems impossible. For against whom will they unite?" (chapter 20, Nałkowska’s emphases).

Despite the narrator's lack of focus on herself, her position on these particular issues is not neutral and is often conveyed through the characters to whom she appears most sympathetic: the two Armenian women, Mademoiselle Hovsepian and "little" Sossé Papazian, and the exiled Russian Madame Wogdeman, who-we eventually learn-is not a disenfranchised Russian princess who had lost all to the Revolution (as the narrator initially assumes), but an exile out of choice, part of the Bolshevik 
establishment who had fled her homeland for moral reasons. These three characters, each in her own way, express aspects of an ideological position or, perhaps more correctly, an existential position that is not exactly pacifistic, but humanitarian, motivated by sympathy for our common humanity, yet one that is ultimately tragic and pessimistic.

Mademoiselle Hovsepian repeats several times, following discussion of some atrocity, what the narrator describes as her "naive" commentary on international relations, which becomes a kind of refrain in the novel: "one nation should not oppress another, n'est-ce pas?" The surface banality, however, conceals a deeper concern. The other Armenian woman, little Sossé, who is confined totally to bed, suffering apparently from both pulmonary tuberculosis and what we might describe today as a form of posttraumatic stress disorder, expresses a more nuanced position from a religious perspective that challenges traditional, nationalistic appeals to God to defend any one nation. Sossé quotes from the traditional liturgy, that of the Armenian Apostolic Church (though the narrator mentions Sossé is from a Catholic-rite family), a prayer she accepts only until the petition intrudes: "grant victory to the Christian armies. O, be Thou the refuge of the Armenian people!" (chapter 22) At this point, she rejects the prayer, claiming it contains a petition God can never grant. According to her, God should not be asked to favor any individual nation and not be invoked in any one nation's defense; she rejects such exclusivity based on the assumption that one nation is intrinsically morally superior to another. Sossé also reinforces the view of human nature as uniformly violent, irrespective of nationhood. Herself a victim of the atrocities against Armenians, she does not regard this persecution as essentially different from other violent events in world history; rather she sees it as a matter of degree, much as Nałkowska regarded war (chapter 36). War is only an extreme form of how humans treat each other anyway: just a matter of degree. 
The position of Madame Wogdeman adds an important dimension: namely, the perception that ideological systems and political structures may change, but people remain essentially the same, with their complex motives, fears, and instincts intact. Hence new regimes merely end up repeating the mistakes and injustices of their predecessors: put in simple terms, power corrupts and is always exercised according to similar methods and predictable patterns of behavior. This is Wogdeman's reason for exile: the wife of a leading Bolshevik, she has witnessed at close hand how Russia's new rulers prove to be as arbitrary and cruel as the tsarist authorities they displaced-some things have remained constant: "war, imprisonments, and the power of some over the lives and deaths of others" (chapter 31 ).

Like the refrain of Mademoiselle Hovsepian, Wogdeman's words form another leitmotif of the novel. The sense that political change brings only a repetition of the same brutal aspects of political repression, imprisonment, and even torture had become deeply ingrained in Nałkowska's consciousness already in the early 1920s, when she witnessed former revolutionary and patriotic leaders exercising power after Poland regained independence. As the wife of Gorzechowski, a professional gendarme, she was aware of the treatment, for example, of political opponents and national minorities in the eastern borderlands. Anticipating the collection of short stories, Walls of the World (1931), inspired by her visits to prisoners in Grodno in the 1920s, Choucas already presents a similar perspective: irrespective of the ideologies of successive regimes, the mechanisms of power remain the same.

The condensed, concentrated, sometimes aphoristic style of language employed by Nałkowska in Choucas also finds its expression in Walls of the World, and reaches its most refined effectiveness in Medallions. These texts deploy an extremely bare, minimalistic yet evocative literary language that hinges on a perfect balance between seemingly detached objectivity (the 
statement of the "facts"), and the emotional and moral shock not articulated directly by the narrator but powerfully conveyed nevertheless to the reader. As with many of Nałkowska's works, not only these, one has the impression of having read a much longer text than one actually has, so dense is the compactness of expression, associations, and implications.

Toward the end of chapter 42 of Choucas, the narrator, on the point of departure from the sanatoria town, sums up her experience of the international community there, again emphasizing her reception of it as humanitarian and existential rather than overtly political. Her first statement may seem banal, recalling the "naive" approach of Mademoiselle Hovsepian:

We people like to speak to one another everywhere in a different way-only our laughter and our tears mean the same across the world [...] And yet, when I resided there for several months among people speaking different languages, I always sensed that we had more in common than not in common. And what we had in common was precisely what was more important-indeed the most important. And the fact that in different locations on earth people make themselves understood through different words [...] was less important.

However, the statement is followed by something less banal: "But precisely this sufficed for things to be as they are, for there to be misunderstandings between them, hatred, war."

Although she was not religious in the sense of belonging to an established creed, Nałkowska describes the religious sentiments guiding the behavior of some of the characters, and which thus shape the broad existential canvas of the novel, including certain contemporary fashions-for example, the debates among the Christian apologist Monsieur de Flèche, the strictly traditional Catholic Madame de Carfort, the "socialist" Totsky who admires progressive contemporary theologians such as Wilfred Monod 
(1867-1943) and Leonhard Ragaz (1868-1945), and the doubting seeker Sossé Papazian, so keenly attuned to suffering. While the novel gives voice to the various existential worldviews apparent in individuals of divergent nationalities and political loyalties, the narrator neither endorses nor contests the theological viewpoints underlying them. Sensitive to the human need for transcendence (which for her was expressed rather in sublime nature or in art), Nałkowska regarded religion as a crucial element in philosophical enquiry and social existence, and therefore includes it in this portrayal of human interaction.

\section{A POLISH "MAGIC MOUNTAIN"?}

The international community, the narrator's underlying concern about ideological extremes, as well as the Alpine sanatorium setting prompt comparisons with Thomas Mann's much more famous (and much longer) novel The Magic Mountain (Der Zauberberg) published in 1924.

Whether Choucas was influenced in some way by Mann's book is hard to establish, but it would seem, in fact, that there was no "influence" as such. The obvious similarities make it difficult to deny. Certain contemporary reviewers already made the comparison but without discussing the possibility of influence. ${ }^{10}$ Curiously, some Polish critics have dubbed the novel the "Polish Zauberberg" even though they too have not delved beyond the mere observance of the similarity (Kraskowska 1999, 49; Bolecki 2003, 2). Yet there is no conclusive evidence that Nałkowska read The Magic Mountain, before or after writing Choucas. She does not mention it in any diary entries written between 1899 and 1939, in which she kept a detailed (though not exhaustive) record of her reading. If she did read it, she would have to have done so in the original German. Mann's novel was published in English for the first time in 1927, in French in 1931, and in Polish not until $1953 .{ }^{11}$ She was fluent in French and Russian, but 
her knowledge of German was weak, at least at that time (i.e., before the German Occupation of 1939-1945). ${ }^{12}$ Even if she did attempt to read it in German, there would not have been much time to do so between the novel's publication in November 1924 and Nałkowska's arrival in Leysin in February 1925. Her own novel began to appear already in August 1926. Seen from this perspective, it would seem that the convergence of setting and theme was coincidental-she just happened to be in a similar environment, met people there from various European countries and their colonies, and chose to write about them.

On the other hand, she must have known of Der Zauberberg's existence: it was reviewed or mentioned quickly in Polish newspapers and journals with which she was certainly familiar, e.g., in the literary newspaper Wiadomości Literackie in April 1925. ${ }^{13}$ Mann was popular among Polish contemporary writers: "German novelists of the Weimar Republic were widely read, especially Thomas Mann" (Miłosz 1983, 421), so the lack of any mention by Nałkowska is puzzling. Indeed, in the four volumes of her diary covering 1899-1939, she mentions only one title by Thomas Mann: Tonio Kröger, which she records on 30 March 1916 as having read $(1976,425)$. She seems unimpressed on that occasion, however, entering only one word beside the title: "uninteresting" ("nieciekawe"). She must have read it in German: Tonio Kröger was not translated into French until 1929 (by Geneviève Maury) and not into Polish until 1931 (by Leopold Staff). ${ }^{14}$

The lack of mention is additionally strange since Nałkowska met Mann when he visited Poland in March 1927 at the invitation of the Polish PEN Club, of which Nałkowska was a prominent member. She describes aspects of his visit in her diary (1980b, 232-36) but does not mention The Magic Mountain, or compare it to her own Choucas. On 14 March she mentions that they had "a few conversations, from which I had the impression we understood one another perfectly-though perhaps this was only one-sided" (232) without recording what they spoke about. 
Furthermore, she wrote a short critical essay on Mann's novella Ein Glück (Szczęście) as part of the special feature marking his visit published in Wiadomości Literackie on 13 March (Nałkowska 1927b, 3). On this occasion it is clear she read Mann in Polish, as the quotations she inserts from the novella are taken word for word from Staff's translation (Mann 1924, 83-101). ${ }^{15}$

In a much later diary entry for October 1944, she records how she had been reading the Confessions of Saint Augustine, specifically mentioning the section on time and remarking how Augustine "anticipates this theme in Proust and Mann" (1996, 630); no mention is made of any specific work. Time, however, is a major concern in The Magic Mountain, indicating perhaps that by this stage at least, she had read it (assuming she meant here Thomas and not Heinrich). Is it possible Nałkowska resisted comparison with Mann and therefore never mentioned his novel? Maybe she thought such comparison might belittle her own work?

It is worth reflecting for a moment on Nałkowska's interpretation of Ein Glück, because it is symptomatic. Whereas she does not record much about Mann in her diary and appears dismissive of Tonio Kröger, she gives this one (early and relatively under-discussed) novella an exceptionally positive gloss. Why? First, because she sees Mann as unusually sensitive for a male writer to the female protagonist's perspective and, second, because he portrays a powerful syndrome in female emotional and erotic life that typifies many of her own protagonists. This is so not only in Choucas (1927) - in the behaviors of Madame Saint-Albert and Mademoiselle Alice (see below) - but also in many earlier and later novels: in Women (1907) or Snakes and Roses (1913), as well as in Bad Love (1928), Boundaries (1935), and The Impatient Ones (1939). Women with strong emotions or erotic feelings suffer in love (i.e., in their sexual relationships with men) because they long for exclusivity and take love too seriously. They observe how their husbands or lovers flirt with other women and thus constantly betray them; yet they are un- 
able to behave similarly. They look on in pain, suffer in their jealousy, but have to constantly strive to appear happy (and hence attractive) - and are thereby deprived of vital energy that might be better spent on pursuing other objectives in life.

An earlier biographer and critic, Włodzimierz Wójcik, sees in Choucas the influence of French writers with whom Nałkowska was familiar:

If we set aside Mann, since the author of The Magic Mountain mainly analyses Europe before the outbreak of the [First World] war and-according to the correct observations of Aleksander Rogalski- "as an artistic interpreter and re-creator of the life of the age, he proved to be strangely insensitive to the fundamental spiritual or intellectual characteristics of the inter-war age," then we can recognize Nałkowska's real literary inspirations as being Barbusse and Duhamel, and possibly also Dorgelès. (Wójcik 1973, 180; Rogalski 1963, 359)

Specific titles mentioned by Wójcik are Henri Barbusse's Under Fire (Le Feu, 1916); Georges Duhamel's Lives of the Martyrs (Vie des martyrs, 1917) and Civilization (1918); and Wooden Crosses (Les Croix de bois, 1919) by Roland Dorgelès (1973, 180). There are indeed several references to Duhamel and to Barbusse in Nałkowska's diary during this period: to her reading of Barbusse's Under Fire, Clarté (1919) and Hell (L’Enfer, 1908) (1980b, 65), to reading Duhamel (1980, 290; see also 292-94: Duhamel visited Poland in October 1926). Dorgelès is not specifically listed by Nałkowska. A quotation from Duhamel's Entretiens dans le tumult: chronique contemporaine 1918-1919 (1919) is included in the text of Choucas (end of chapter 31).

What then does Choucas have in common with Mann's novel, and how does it differ? Mann's book was set in Davos, in a German-speaking region in the eastern part of Switzerland; Nałkowska's is set in a French-speaking environment near Lake 
Geneva. The historical period is also different: Mann's work deals with European society before the First World War and ends with the main protagonist's participation in the war, one of countless numbers who perished on its battlefields. Nałkowska's reflects society after the war, in the mid-1920s, when various extreme ideologies were gathering momentum both at home in Poland and in Europe. Her novel not only reflects on the barbarism and losses of the First World War (the story of Monsieur Verdy's son) and the genocide against Armenians. It also illustrates other catastrophic developments: the story of Est, the Jewish student from Bucharest and his experience of antisemitism; the abuses of Soviet power witnessed by Madame Wogdeman; the struggles of various colonies in North Africa and the Far East against their imperial masters, and the suppression of liberation movements with violence. On the other hand, Nałkowska's narrator seems to focus much more on the national and cultural elements that divide people rather than on the philosophical or ideological. There are no fundamental conflicts on the scale of that between Naphta and Settembrini, or between their intellectual approach to life and the Dionysian attitude embodied in Mynheer Peeperkorn.

Finding herself in a similar environment to the fictional Hans Castorp in Davos, similarly exposed to a cross-section of representatives of the European nations-mostly privileged people with a somewhat superior attitude to those down below, it is not surprising that Nałkowska's narrator also speaks about the things that impressed the writer the most, namely people's attitudes toward each other, as well as aspects of their daily routine: the cure, mealtimes, walks in the mountains, the magnificent scenery, the political debates of the day. The society the narrator describes, however, does not include only people suffering from tuberculosis. Monsieur Curchaud has come to enjoy the winter sports, as have the English couple Mr and Mrs Vigil. Others are refugees housed in the sanatoria hotels and pensions by 
the Red Cross, namely the three Armenians. The Russians, Madame Wogdeman and Mademoiselle Alice, also refugees, similarly have nowhere else to go. Others are indeed patients suffering from either bone (Miss Norah) or lung (Est, Verdy, Fuchs) tuberculosis; Madame de Carfort is likewise on a cure but we are not told anything other than that the climate in Morocco is harmful to her condition.

Unlike Mann, Nałkowska's narrator is not interested in the strictly medical aspects, and the fascinating history of Leysin and its pioneering doctors are mentioned only in passing. The description of Norah lying naked on her balcony exposed to the healing rays of the sun is an exception. There is no figure comparable to Mann's Hofrat Behrens; no detailed descriptions of medical examinations, of how X-rays work (a new technology in those days), or of how lung operations are performed. However, like Mann, she also draws a parallel between bodily sickness and moral sickness, and the sickness of ideological extremes.

Choucas is not about sickness as such, however. In both novels, discussions of political and philosophical differences may take place with impunity in the rarefied environment above the clouds, but when they are put into practice down in the real world - the colonializing imperialism, for example, of Madame de Carfort or Carrezales or Curchaud-the violence meted out to their opponents, to those less powerful than the perpetrators, can be catastrophic. At the same time, however, despite her tolerant and progressive spirit, Nałkowska's narrator is not entirely free of colonial attitudes: albeit in a positive manner, she uses such vocabulary as "oriental" (Madame de Carfort's beauty) or "exotic" (Mademoiselle Hovsepian) to describe human Others, i.e., people not from the mainstream cultures of contemporary Europe (among which she appears to include herself as a Polethough she is sensitive to the fact that only Monsieur Verdy expresses any interest in Poland); as a colonial, Madame de Carfort is portrayed as more stereotypically French than the French. 
Meanwhile the rarefied moral climate is paralleled by the rarefied air: at such high altitude-looking down on the world from privileged heights, removed from "normal" social intercourse-regular responsibilities no longer seem to apply. During the Carnival party held in the villa-pension (chapter 18), which recalls many precise details of the Carnival scene in The Magic Mountain (the portrayal of this event is strikingly similaralthough being resident at the same time of year, it would not have been unexpected that she would attend a similar party as Hans Castorp), Nałkowska's narrator speaks of how the guests and patients seem like a group of lost children for whom no one is responsible:

I imagined they were all like children. Unprotected and exposed to every danger. So alone, thrown back on their own resources in this alien mountain house amid the snows. Who was to keep watch over them? [...] healthy and sick, young and old-a collection of thoughtless children confronted by the seriousness of life for whom no one was responsible.

\section{NOVEL VERSUS DIARY}

While in Leysin, Nałkowska recorded in her diary her observations of the actual place and the people whom she encountered, as well as aspects of her own internal life-many elements of which also find their way into the novel (1980b, 153-70). At the time of Nałkowska's stay (early February to mid-April 1925), Leysin was a well-known resort, second only in Switzerland to Davos. ${ }^{16}$

The novel, as already mentioned, does not refer to Leysin by name, while the narrator seems more interested in the topography and the beauties of nature than in the medical cures, and stands as an independent text in its own right, separate from the literal, physical place that inspired it. However, the diary illuminates particular inspirations and is even the source of precise phrases and descriptions directly transposed into the novel's 
text. For example, many exact details appear both in Nałkowska's novel and in her diary: the cog (or rack and pinion) train, the viaduct, the steep tunnel inside the rocks, the top station with its walkway over a bridge into the second floor of the hotel, the Grand Hôtel itself, the heliotherapy treatment undertaken in the novel by Miss Norah, the repos complet (mentioned in chapter 21 of the novel), a two-hour period of daily rest and total silence recommended by the doctors and enforced by the local police. Also in the diary are the prototypes for many of the novel's characters.

The correspondences and discrepancies between the diary record (which, as also mentioned above, was not generally available to readers or researchers until 1980) and the novel also reveal Nałkowska's writing technique: she recorded what she observed as she went along in order to return to it later and exploit the material for fictional-artistic purposes when she had more time and found herself in surroundings more conducive to creative writing. The diary could be said to fulfil several functions at once: it was a record of witnessed people, places, and events (which to some extent we may regard as objective, or "true," albeit selective); a repository of material gathered for future artistic exploitation-what Hanna Kirchner calls a "literary larder" (2011, 799); a "literary" reworking of the writer's experience (Nałkowska said of herself that she perceived everything "in a literary way"); and a means of actually "writing herself," i.e., a medium through which she processed material and reflections that went into her own self-creation.

The modest pension or small sanatorium, usually described as a "villa" (in the contemporary context, this implied a modern building constructed from stone, as opposed to a traditional wooden chalet), is also not named in the novel. The anonymity, however, is not maintained for long, since the location can easily be established on the basis of the configuration of mountains and valleys visible from the villa's balconies: the position of the Dents 
du Midi, the Chamossaire, the valleys of the Rhône and Grande Eau. We know from the diary $(1980 \mathrm{~b}, 154)$ that the villa-pension was called "Pension de la Forêt." Its position can be roughly located from that very configuration of mountains, although Nałkowska does not give the address, except its being in LeysinFeydey (the top part of the village, where the large sanatoria were built from the 1890s). It appears the pension soon changed its name, because it does not appear in subsequent lists of sanatoria, hotels, and pensions in Leysin. ${ }^{17}$ It has been possible, however, to identify the building once housed by "Pension de la Forêt" as the one now consisting of private flats called "La Coccinelle" on Avenue Sécretan, the road that leads horizontally west across the mountainside from the station at Leysin-Feydey, a position that also coincides with incidents in the novel: it is clear from the novel's closing scene, for example, that the departing train can be observed from windows and balconies of the pension.

The trains appearing in the novel are described in the diary and still run on the same routes today. For example, the grumpy, morose "personality" of the cog train (chapter 15), recorded in the diary entry for 12 February 1925, appears as follows: "From Aigle we were carried up the mountain by the little electric cog train, groaning softly from exertion and dissatisfaction" (1980b, 156). Aigle is not mentioned by name in the novel. In the diary entry for 4 April, she describes a five-kilometre walk down from Leysin to neighbouring Le Sépey, where she and her companions board a different train: the narrow-gauge, single-track electric train that takes them up to Les Diablerets through magnificent scenery along cliff ledges and over narrow bridges above dramatic chasms, and then back down to Aigle and the flat Rhône Valley (1980b, 162-164). Again, in the novel, she does not mention by name the precise geographical locations, but elements of this journey are transcribed into chapter 25 , sometimes in precise detail or even word for word, such as the description of the local peasant women in their black hats and dresses spread- 
ing manure over the fields (1980b, 163). Other descriptions of the mountains, the local natural world, the tentative coming of spring, various hikes, and other expeditions are similarly transcribed from the diary into the text of the novel.

Sometimes, Nałkowska exploits details she has recorded but gives the place another name: for example, on 15 February, she describes the hotel where they spent the first few days of their stay, calling it the Hotel "de la Gare," with its fiery Spanish proprietess who loved to dance to a relentless pianola ("in the morning in her dressing-gown, in the afternoon in a jumper, and in the evening in a revealing, low-cut, brightly coloured dress,"), Italian waitress with gold headband and gold earrings, and husband who played billiards and accompanied his wife's singing on the mandolin (1980b, 157-58)-all details precisely transcribed into chapter 17 of the novel, where the hotel is renamed Toscana. Her most evocative descriptions of interiors are reserved, however, for the Palace Hotel and its Jardin d'hiver (chapter 15). This location is mentioned in the diary only in passing, as the venue for the charity bazaar (described in chapter 23), and as "the most beautiful hotel in the vicinity" (1980b, 160). However, the hotel appears in detail in the novel itself, and a visit to the location identifies beyond doubt that the inspiration was the Grand Hôtel now owned by the Leysin American School, and recently renovated as "La Belle Époque" campus. All the details described by Nałkowska's narrator conform to the actual building-from the fact that the hotel is "invisible" from below, hidden by forest and rocks, to the footbridge that connects the uppermost station of the cog railway to the second floor, to the stained-glass cupola in the ceiling of the conservatory.

The diary also mentions individuals who were clearly prototypes for characters in the novel, although here Nałkowska changes their names as well as other specific details: the beautiful wife of a French officer resident in Morocco (1980b, 165-66); a Spanish gentleman who supports not only Alfonso XIII and 
the military dictator Miguel Primo de Rivera, but their colonial policy in North Africa (165); the group of Armenian exiles, witnesses to the genocide $(158,168)$; the Romanian student who is a victim of antisemitism (167). Under altered names, their personalities, opinions, and prejudices are reworked into the novel's text. Nałkowska also mentions in these diary passages what appear to be the same books discussed by characters in the novel, and they are therefore a useful source of background information, as no Polish edition of the novel to date identifies them. These are explained in notes to the text of the translation.

What is especially interesting, however, is that Nałkowska puts into the mouths of entirely fictional, invented figures-or rather, figures for whom she provides no "real-life" models in the diary-additional passages from the diary that relate to herself. She transposes even exact sentences, where she expresses her own fears, for example about ageing, from the diary into the novel, putting them into the mouth of the fictional Madame SaintAlbert. This raises a question as to the purpose of this character in the novel, as does the presence of other female characters, notably Mademoiselle Alice and Madame Wogdeman, for whom no obvious models likewise appear in the diary (no post-1917 Russian exiles are mentioned in the diary-only the model for Monsieur Totsky, who, like the fictional Totsky, is not an exile in the same sense as Wogdeman, being described rather as a Swiss citizen of Russian origin). One should beware of claiming that these fictional female characters are to some extent the portes paroles of the narrator, and also of the author herself, but I do suggest it as a possibility.

In the diary entry for 13 March 1925, we read the following confessions, which coincide almost word for word with sentiments expressed in chapters 15 and 27 by Madame Saint-Albert:

Earlier in life I flattered myself that I would know how to grow old. And yet I have experienced this very crisis with great dif- 
ficulty, deeply and precisely. I look at everything around me, at everything current in life, as though it were something that has come after me. I don't look at life, I look back at it. And this is not some serene form of melancholy. These are attacks of despair, which can only be silenced or suppressed by the thought that there is a way out: that I will die. (1980b, 160; Nałkowska's emphases)

The narrator of the diary has not yet reached, unlike Madame Saint-Albert, a point of no return: she is still moved by the beauties of nature, still reads and enjoys a vast number of books, and still knows how to keep up outward appearances. Yet, the knowledge of her ageing weighs heavily on her perception of herself, her vanity and growing sense of worthlessness. The words contained here are repeated more or less verbatim in the novel by Madame Saint-Albert (chapter 27):

I am simply ashamed to be old. My eternal aesthetic approach to myself is bankrupt.-I talk more and more about other people, think about other people-in order to deflect my own attention away from myself. How ashamed I am of the fact I'm no longer slim and especially that ultimately it's all one and the same, what I'm like. But-I repeat-outward appearances are maintained, I am, as though nothing had happened [...]. And despite enjoying and flaunting my youth since I was fifteen years old, it is only now that I realize that youth is a trump card. Youth is not a state of being, it's a value, an addendum to everything else. And old age is the taking away of value from everything. (1980b, 160-61)

The role of Mademoiselle Alice in the novel and what she may represent or convey is not so obvious or explicit, nor is its connection with Nałkowska. In the novel, Nałkowska's narrator attempts to explain the particular crisis experienced by the twenty-two-year-old Alice. Young and attractive and emanating a strong sexual charge, Alice is driven by personal vanity and 
also by her innate and entirely natural sexual instincts to actively seek the attention of men. At one and the same time, however, she feels a compulsion to resist their demands once their desire has been seriously aroused in order to claim-irrespective of her own behavior-that they do not respect her, thereby eventually rejecting and attempting to shame and humiliate them. Alice attracts the narrator's interest, not because her dramas are important in themselves, but because she perceives Alice as exemplifying a particular syndrome in culturally determined, womanly behavior: "a specific pattern of constantly shifting equilibrium between defeat and victory. Her need to arouse passion in men was just as strong and irrevocable as her need to triumph over it" (chapter 16).

Torn perpetually between her need to flirt, to assert her sexuality and attract admirers, and to triumph over them by keeping intact her virginity and self-respect like some inviolable fortress, Alice is shown to truly suffer existentially. When she falls in love seriously and unrequitedly, this time with Monsieur de Flèche, she is unable to control her instincts or conceal them from him or from other people. Is the narrator (and her author) making some statement here about female sexuality and the contemporary perceptions of it-even recalling perhaps the young Nałkowska's demand (at the 1907 Polish Women's Congress) for the rejection of the double standard, for women's sexual equality with men and what she called at that time their right to "the whole of life"? On the one hand, Alice is an innocent, a natural-she possesses no stereotypical feminine wiles and is unashamedly candid in her confessions, since her intention is not to harm others, only to satisfy her egocentric need for "danger" and "anguish." On the other hand, her suffering could be perceived as the consequence of her lack of education and self-understanding, which leave her unable to manage the power of her own feelings, or quite simply: biology. On several occasions in the novel, she is compared to spring - a passionate and natural being, whose instinctive reac- 
tions are an affront to the majority of society. The narrator passes no judgement, merely lends a sympathetic ear to her confidences.

Nałkowska remained locked in her Modernist conviction of the ultimate incompatibility of the sexes and of the role of biology in determining fatal attraction, especially in women. However, the human experiences portrayed in the novel, both intimate and collective, are not so much-or not only-autobiographical or exclusive to women, as reflective of Nałkowska’s pessimism concerning human interrelationship in general.

\section{NOTES}

1. The first volume of the diaries to appear, censored in communist Poland, was entitled Wartime Diaries (Dzienniki czasu wojny, 1970), republished in 1996 as volume $5(1939-1944)$ of the complete set with the excised parts restored. The other volumes are: 1: 1899-1905 (published 1975); 2: 1909-1917 (1976); 3: 1918-1929 (1980); 4: 1930-1939 (1988); 6: Part 1, 1945-1948, Part 2, 1949-1952, Part 3, 1953-1954 (2000). All volumes are edited and annotated by Hanna Kirchner and published by the Warsaw publisher Czytelnik. Apart from Kirchner's recent chapter “Dzieło nieznane" (2011, 789-826), the following critical works may be of interest: Marszałek 2003; Fołtyniak 2004; Fitas 2011.

2. Here there is no space to provide a complete survey of her literary output. Readers of Polish are referred to the recent biography by Hanna Kirchner, which also contains analytical chapters on her literary works, Nałkowska albo życie pisane (Warsaw: Wydawnictwo W.A.B., 2011). Introductory surveys may be found (in English) by Kirchner (1999) and Borkowska (2001a, 255-321; and 2001b, 150-55), and (in Polish) in Ewa Kraskowska (1999, 38-74). See also my brief critical review of her pre1939 works "Politics and Ethics of Human Relations" in A History of Polish Literature and Culture: New Perspectives on the Twentieth and Twenty-first Centuries, edited by Przemysław Czapliński, Joanna Niżyńska and Tamara Trojanowska [forthcoming]. The only critical assessments specifically of Choucas of which I am aware, apart from the contemporary 1927 reviews, 
are the chapter in Kirchner's book "Cudzoziemskie ptaki” (2011, 235-46), the chapter in an earlier biography (Wójcik 1973, 170-208), and the article by Włodzimierz Bolecki (2003).

3. My Animals (Moje zwierzęta, 1915), Book about My Friends (Ksiegga o przyjaciólach, 1927), and Among Animals (Między zwierzętami, 1934).

4. Zofia Nałkowska (2000) Medallions, translated by Diana Kuprel. Evanston, IL: Northwestern University Press.

5. All translations from Nałkowska's diaries are my own-U.P.

6. A list of the reviews is provided in Słownik współczesnych pisarzy polskich (Warsaw: Państwowe Wydawnictwo Naukowe, Volume 2: 534, 1964). The reviews are discussed by Wójcik $(1973,176-77)$ and Kirchner $(2011,239)$.

7. See, for example: Handbook of the Birds of Europe, the Middle East and North Africa: The Birds of the Western Palearctic. Volume 8: Crows to Finches (Oxford: Oxford University Press, 1994); and Crows and Jays: A Guide to the Crows, Jays and Magpies of the World, edited by Steve Madge and Hilary Burn (London: Croom Helm, 1994). I am grateful to Erika and Nick Panagakis for identifying the English name of the bird in question as the Alpine chough.

8. I am likewise indebted to Swiss ornithologist Jérôme Fournier for providing this extra information which explains why Nałkowska used the name choucas and clears up the confusion over whether they are jackdaws, and for taking me to see the birds in their summer habitat in the mountains above Leysin.

9. Stefan Żeromski (2007), The Coming Spring, translated by Bill Johnston (Budapest: Central European University Press).

10. See the untitled review undersigned by A. Stawar in the journal Dźwignia no. 2-3 (1927): 55-57.

11. English translation by H.T. Lowe-Porter (London: Secker and Warburg, 1927); French by Maurice Betz (Paris: Fayard, 1931). The Polish version was published in two volumes in 1953, volume 1 translated by Józef Kramsztyk, volume 2 by Jan Łukowski (pseudonym of the philosopher Władysław Tartarkiewicz). 


\section{Ursula Phillips}

12. I am most grateful to Professor Hanna Kirchner for our discussions on this topic on 24 April 2012 and again on 30 March 2013. Professor Kirchner sees no influence of The Magic Mountain on Choucas.

13. Review entitled "Nowa powieść Tomasza Manna 'Der Zauberberg" undersigned by “ $\mathrm{jk}$ ” in Wiadomości Literackie, no. 15 (1925): 1.

14. She records having read a few early works by Mann's brother, Heinrich Mann (1871-1950), to which she seems to have been more positively inclined, including Diana (one of the three parts of Die Göttinnen oder Die drei Romane der Herzogin von Assy, 1903, translated into Polish in 1930), recorded as read on 21 August 1912 (1976, 235); Źli (Die Bösen, 1908), recorded as read on 17 January 1916 (1976, 422); and Cudowne (Das Wunderbare. Novellen, 1897), recorded as read on 29 September 1916 $(1976,463)$. Although she records the titles in Polish, it seems she read them in German.

15. The 1924 collection of Staff's translations of Mann includes six stories, although it is entitled only Tristan (Mann, 1924). Nałkowska's essay was republished in the volume Widzenia bliskie i dalekie (Nałkowska 1957, 110-12).

16. I am most grateful to local historian Véronique Bernard for providing me with materials on Leysin at the time of Nałkowska's stay. For a detailed picture of Leysin's history as a sanatoria village, see her bilingual dvd film: Leysin, 100 ans d'histoire 1860-1960/ Leysin, 100 Years of History: a production by Véronique Bernard and Pierre-Alain Frey (2008). It was from an old photograph shown in this film of the Pension de la Forret (the name is inscribed on a side wall) - a former clinic for child patients, subsequently a boardinghouse, and now a block of private flats that was long ago renamed-that I was able to identify the building where Nałkowska stayed in 1925. On the history of Leysin, see also Liliane Desponds, Histoire et reconversion d'une ville à la montagne (Yens-sur-Morges: Editions Cabédita, 1993).

17. It is not listed, for example, in Leysin, station medicale. Témoignages recuellis par Maurice André (Le Mont-sur-Lausanne: Editions Les Iles futures, $2 \mathrm{~d}$ ed., 2007). 


\section{BIBLIOGRAPHY}

Bolecki, Włodzimierz. 2003. "Ludobójstwo i początki prozy nowoczesnej (Choucas Zofii Nałkowskiej)." Arkusz 5: 31-49.

Borkowska, Grażyna. 2001a. Alienated Women: A Study on Polish Women's Fiction 1845-1918, translated by Ursula Phillips. Budapest: Central European University Press.

2001b. "The Feminization of Culture: Polish Women's Literature, 1900-1945." In A History of Central European Women's Writing, edited by Celia Hawkesworth, 150-64. Basingstoke: Palgrave Macmillan.

Fitas, Adam. 2011. Zamiast eposu. Rzecz o Dziennikach Zofii Nałkowskiej. Lublin: Wydawnictwo Katolickiego Uniwersytetu Lubelskiego.

Fołtyniak, Anna. 2004. Między "pisać Nałkowskg" a Nałkowskiej "czytaniem siebie." Narracyjna tożsamość podmiotu w "Dziennikach." Kraków: Universitas.

Kirchner, Hanna. 1984. "Nałkowska-prolegomena do Gombrowicza." In Gombrowicz i krytycy, edited by Zdzisław Łapiński, 573-86. Kraków: Wydawnictwo Literackie.

___ 1999. "Zofia Nałkowska." In Dictionary of Literary Biography, Volume 215: Twentieth-Century Eastern European Writers, First Series, edited by Steven Serafin, 273-82. Detroit: Gale Research Company. - 2011. Nałkowska albo życie pisane. Warsaw: Wydawnictwo W.A.B. Kraskowska, Ewa. 1999. Piórem niewieścim. Z problemów prozy kobiecej dwudziestolecia międzywojennego. Poznań: Wydawnictwo Naukowe Uniwersytetu im. Adama Mickiewicza.

Mann, Tomasz. 1924. Tristan, translated [from German into Polish] by Leopold Staff, 83-101. Warsaw: Nakładem B. Rudzkiego.

Marszałek, Magdalena. 2003. “Życie i papier." Autobiograficzny projekt Zofii Nałkowskiej “Dzienniki” 1899-1954. Kraków: Universitas.

Miłosz, Czesław. 1993. The History of Polish Literature. 2d ed. Berkeley: University of California Press.

Nałkowska, Zofia. 1927a. Choucas. Powieść internacjonalna. Warsaw: Gebethner i Wolff. 1927b. "Szczęście." Wiadomości literackie 11: 3. 


\section{Ursula Phillips}

1938. Choucas. Powieść internacjonalna. 2d ed. Lwów and Warsaw: Książnica-Atlas.

1957. "Szczęście." In Widzenia bliskie i dalekie, edited by Tadeusz Breza, Bogusław Kuczyński, Wilhelm Mach, and Jerzy Zawiejski, 110-12. Warsaw: Czytelnik.

-1960. Choucas. Powieść internacjonalna. Warsaw: Czytelnik.

__ 1975. Dzienniki. Volume 1: 1899-1905, edited and introduced by Hanna Kirchner. Warsaw: Czytelnik.

—. 1976. Dzienniki. Volume 2: 1909-1917, edited and introduced by Hanna Kirchner. Warsaw: Czytelnik.

—. 1980a. Choucas. Powieść internacjonalna. Warsaw: Czytelnik.

—. 1980b. Dzienniki. Volume 3: 1918-1929, edited and introduced by Hanna Kirchner. Warsaw: Czytelnik.

—. 1988. Dzienniki. Volume 4, Part 2: 1935-1939, edited and introduced by Hanna Kirchner. Warsaw: Czytelnik.

—. 1996. Dzienniki. Volume 5: 1939-1944, edited and introduced by Hanna Kirchner. Warsaw: Czytelnik.

—2000. Medallions, translated by Diana Kuprel. Evanston, IL: Northwestern University Press.

Rogalski, Aleksander. 1963. Most nad przepaścia. O Tomaszu Mannie. Warsaw: Instytut Wydawniczy PAX.

Wójcik, Włodzimierz. 1973. Zofia Nałkowska. Warsaw: Wiedza Powszechna. 
